\title{
Weak Oil Prices and the Global Economy
}

\author{
Mehdi S. Monadjemi ${ }^{1 *}$ \\ ${ }^{1}$ School of Economics, University of New South Wales, Sydney, Australia \\ *Mehdi S. Monadjemi, E-mail: mehdimonadjemi@yahoo.com
}

Received: October 20, 2016

Accepted: October 24, 2016 Online Published: October 27, 2016

doi:10.22158/jepf.v2n2p353

URL: http://dx.doi.org/10.22158/jepf.v2n2p353

\begin{abstract}
The results of this study indicate that changes in global output have significant impact on real oil price fluctuations. Sharp rises in oil prices in 2008 and recent slump in price of oil are evidence of a strong influence of demand one fluctuations of energy prices. The empirical results of the study are based on VAR impulse response functions and Granger Causality test using monthly data 1970-2016. Furthermore, the effects of political development in the Middle East on real oil prices are not supported in this study.
\end{abstract}

Keywords

oil prices, global output, real interest rate, demand for energy

\section{Introduction}

The oil prices are influenced by international demand and supply for oil as well as expectations. The demand for oil is a function of growth rates of oil importing countries and availability of oil substitutes. The supply of oil is influenced by the political developments in Middle East (35 percent of world's oil is produced in Middle East), world's rate of interest and transportation and insurance costs of transporting crude oil to importing countries.

Oil Prices have fallen from peak of 145 US dollars per barrel in July 2008 to as low as \$28 per barrel in January 2016. This is 81 percent in eight years after nearly five years of stability. Weaker oil prices adversely affect the economy of oil exporting counties such as Russia, Iran, Saudi, Kuwait, Iraq, Nigeria and Venezuela whereas it helps oil importing countries like China, India, Japan and most of the Western European countries.

Three factors contribute to weaker oil prices. Reduced demand because of weaker global economic activity, higher efficiency, and larger substitution of other fuels for oil. Second, United States has managed to be the world's largest oil producer. Although US is not a net exporter of oil, but its imports is significantly less, causing excess supply in the market. Finally, the Saudis and Gulf allies have decided not to reduce their share of production to halt the price fall. These countries may reduce production sharply, but their refusal to do so is politically motivated since countries such as Iran and 
Russia will benefit from their action. With large foreign reserves and low cost of oil production (around \$5-6 per barrel), Saudi Arabia can easily afford lower oil prices for an extended period. Falling oil prices have political implications for the oil exporting countries. In most of these countries oil revenue is the source of financing their social welfare programs. Falling oil revenues causes larger budget deficits and curtailment of social welfare expenditure.

The purpose of this paper is to show the relationship between oil price fluctuations and the global economy. Section 1 presents historical movements of oil prices and a brief literature review. Section 2 develops a theoretical model for the relationship between oil prices and the global output. Empirical results are discussed in Section 3. Summary and concluding remarks are offered in Section 4.

\section{Oil Price Fluctuations and the Review of Literature}

Figure 1 shows that crude real oil prices from its peak in July 2008, slumped to 40 dollars per barrel in November 2008. It remained relatively stable at 80 dollar per barrel until July 2014. The lowest price was 28 dollars per barrel in January 2016.

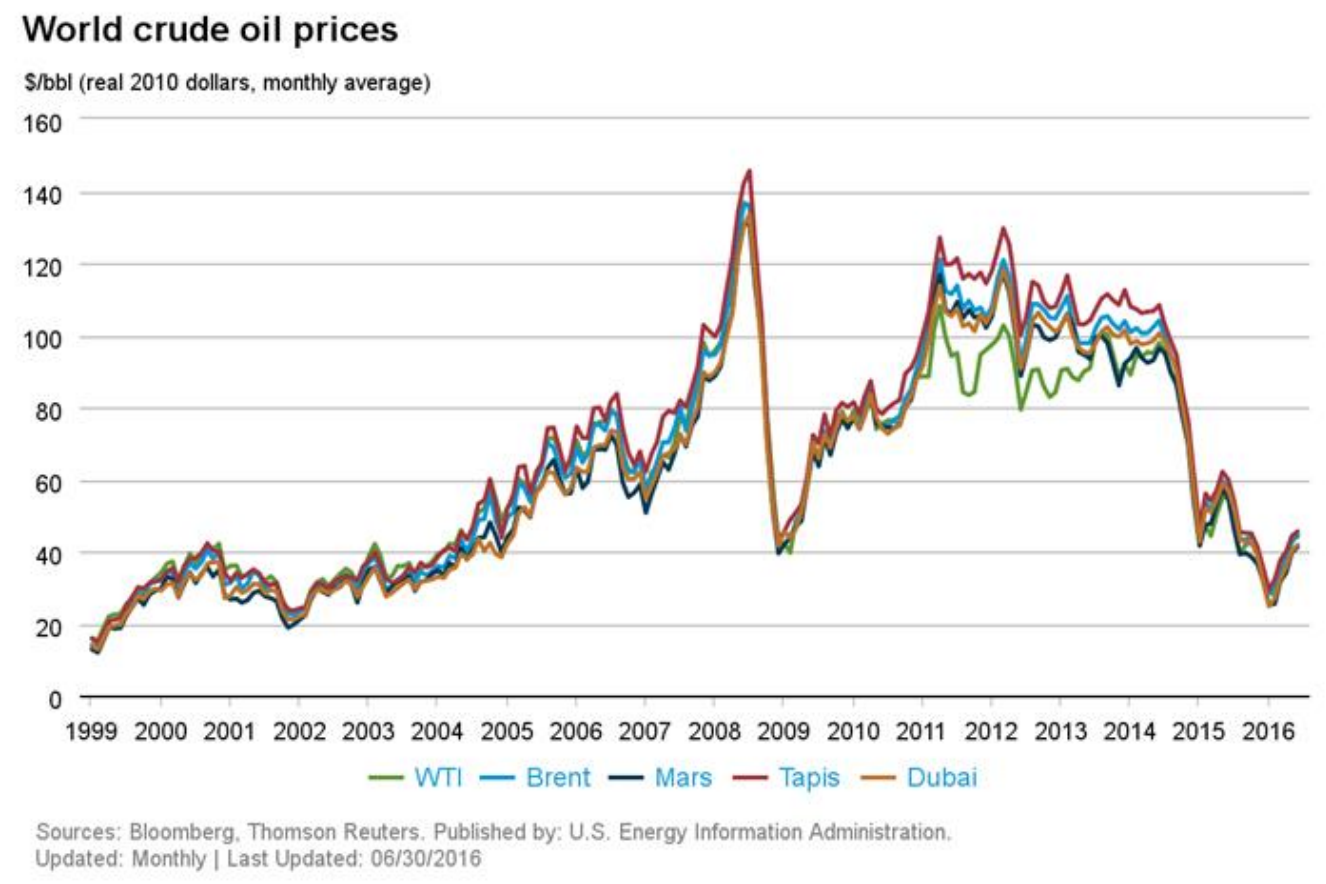

Figure 1. Monthly Average Crude Oil Prices

The International Energy Agency (IEA) in June 2016 report "Global oil stock are still building" announced that global demand for oil will grow by 1.4 million barrels per day (bpd) this year to 96.1 million bpd, revising up last month's forecasts of a 1.3 million bpd rise. IEA said "the existence of very high oil stocks is a threat to the recent stability of oil prices".

The IEA argued that crude prices had dropped from an early June peak of above $\$ 52$ dollars per Published by SCHOLINK INC. 
barrel to $\$ 45-\$ 50$ range which is in contrast to the sharp daily price falls at the beginning of this year. "Our underlying message that the market is heading to balance remains on track, but the modest fall back in oil prices in recent days to closer to $\$ 45 / \mathrm{bpd}$ is a reminder that the road ahead is far from smooth", the IEA concluded.

The OPEC predicted that the global supply glut would ease this year and 2017, non OPEC producers, particularly the United States, reduce production. OPEC also predicted that global demand growth rise in 2017 to let the market to remove excess supply.

For 2017, the IEA forecast a 1.3-million barrel per day increase in demand to 97.4 million, mainly extra demand in non-OECD countries, in particular India and China.

The IEA forecast Europe as being cautious for oil consumption with growth in demand reaching highest in the second quarter of this year. But this may be temporary because uncertainty of Britain's vote to exit the European Union. The agency also noted that the Middle East's market share of global oil production had increased to 35 percent, the highest since the late 1970s.

The IEA forecast that a "modest deceleration" in global oil demand growth was foreseen for 2017, however, easing to 1.3 million bpd taking average deliveries up to 97.4 million bpd. The majority of the projected upside in 2017 was attributable to non-OECD consumers, chiefly in Asia and especially India. "In China, data for May suggests that year-on-year demand growth was only 130,000 bpd, part of a recent trend of smaller increases. For the U.S., estimated gasoline deliveries in April were up just 75,000 bpd up on the year earlier and $410.000 \mathrm{~b} / \mathrm{d}$ below our expectations. The IEA argues that the effects of Brexit will be negative than positive for European oil demand. While demand growth looked uncertain, on the supply side, the IEA noted that non-OPEC production remained on course to fall further this year, by 900,000 bpd to 56.5 million bpd, before staging a modest recovery in 2017 and rising 200,000 bpd. On the contrary the OPEC group keeps on producing at record rates. The IEA said OPEC crude oil output during June was at the highest level since July 2008, with production at 33.21 million bpd".

Finally, in conclusion, the IEA was cautious. The market is heading to remain in balance, but the moderate decline in oil prices in recent days to closer to $\$ 45$ per barrel is an indication that the future of oil market is not smooth.

The literature on oil price fluctuations is dominated by articles written by Hamilton $(2009,2011)$ and Killian (2009) and Brasky and Killian (2004). Hamilton (2011) notes that 2007/2008 oil price rise was mainly as a result of the existence of a strong demand against a relatively stable supply.

Hamilton (2011) maintains that, irrespective of its origin, oil price rises have contributed to the recessions in the United States in the post war period. The author argues that the effect of the recent oil price shock on the US economy was not any different in terms of declining growth of output and real consumption. Hamilton believes that without significant contribution oil price rise in 2008 the subsequent recession would not have occurred in the United States. Killian (2009) and Monadjemi and Lodewijks (2011) empirical results provided evidence in support of strong influence of global output on oil prices. Killian (2009) maintains that the effects of oil price rise on the US economy have not 
occurred after early 1970s oil price shock. Empirical evidence in Monadjemi (2016) showed a high correlation between oil price fluctuations and the Australian dollar.

\section{The Theoretical Model}

The relationship between oil price and the global output is both ways. Changes in the global economy output affect the demand for oil and the price of oil. However, changes in oil prices influence the growth of world output. Accordingly, the regression coefficient of global output in the regression of oil price is biased. Some studies such as Killian (2009) have used vector autoregression (VAR) to investigate the investigate the effects of global output on oil prices. In a VAR model every variable is a function of its own lag and lagged values of other variables in the model. The coefficients of a VAR model do not convey useful information. However, Impulse Response Functions (IRF) and Variance Decompositions (VD) derived from the VAR model are useful showing effects of a shock in one variable on other variables in the model.

Equation 1 is a VAR model showing real oil prices and other variables that enter the model of oil price.

$$
z=\left(y_{t}, o_{t}, p_{t}, r_{t}\right)
$$

In equation $1, y_{t}, o_{t}, p_{t}$ and $r_{t}$ are global output, real oil price, political events in Middle East, and real interest rate. The effect of world real interest rate is on the supply of oil. When real rates are high producers are encouraged to pump more oil and invest in interest bearing assets. The opposite takes place when real interest rates are low. It is expected that oil price fluctuations and real interest rates to move in the opposite direction.

Major political and financial developments int since 1970s are listed in Table 1.

Table 1. Major Political and Financial Event

\begin{tabular}{llll}
\hline Events & Date & Average Real Price of Oil in \$US & Standard Deviation \\
\hline Arab Oil Embargo & $1973-1974$ & 7.31 & 4.32 \\
Iranian Revolution & $1978-1979$ & 21.71 & 10.16 \\
Iran-Iraq War & $1980-1981$ & 35.85 & 2.36 \\
Iraq Invades Kuwait & $1990-1991$ & 19.33 & 1.56 \\
Asian Financial Crises & $1987-1991$ & 17.52 & 1.91 \\
Great Financial Crises & $2007-2009$ & 76.25 & 24.25 \\
\hline
\end{tabular}

Note. The Overall standard for the sample period 1970-2014 was 20.15. Most of the fluctuations of the real oil prices occurred in responses to Arab oil embargo, the Iranian revolution and substantial variations in 2008 mainly as a result of strong demand for oil from China and India. Comparisons of standard deviations in different periods of political events indicate that after 1970s, political events in the Middle East did not play a major role in fluctuations of oil prices, also observed in Killian (2009). 


\section{Empirical Results}

All of the data in this study are monthly observations. The data on interest rate, price level and GDP were collected from the OECD national income account series. The GDP series were converted from quarterly observations to monthly series using Eviews command. Oil price series is the price of crude oil per barrel in US dollar. The US real GDP and the US real interest rates were substituted for world output and world interest rate. A 0.1 dummy variable was used to represent the effects political development in the Middle East. The value of 1 was assigned to the dummy variable during the periods listed in Table 1 and 0 in the other months.

The response of oil prices to political dummy variable was insignificant, not presented among above results. The results presented in Figures 2 and 4 show that the relationship between oil price changes and output is both ways. Oil prices affect output and world output affects oil prices. This result was supported in Killan (2009). Figure 3 indicates that oil price changes are negatively related to real interest rates. Furthermore, the weakness of oil prices in recent period and their strength in 2007 to 2008 are supportive of the effects of global demand on oil price fluctuations.

Granger causality test was used for further investigation of the relationship between real oil prices and the global output. The results are presented in Table 2.

Table 2. Granger Causality Test Results

\begin{tabular}{lll}
\hline Hypothesis & F statistics & Probability \\
\hline Real oil price doesn't GC US real GDP & 1.20 & 0.31 \\
US Real GDP doesn't GC real oil price & 3.65 & 0.00 \\
\hline
\end{tabular}

In the above table GC stands for Granger Causality. The results are based on monthly data 1970-2014. High values of $\mathrm{F}$ statistics and low probabilities indicate rejection og null hypothesis.

The results of Granger Causality (GC) test reject the hypothesis that changes in US output have no effect on real oil prices. However, the hypothesis of real oil price changes not affecting US output cannot be rejected. Further evidence on the effects of global output on real oil prices can be provided by examining the GC test results after removing from the real oil price the observations corresponding to 2007-2009 when the demand for oil was very strong. The results of the new experiment are presented in Table 3.

Table 3. Granger Causality Test Results

\begin{tabular}{lll}
\hline Hypothesis & F statistics & Probability \\
\hline Real oil price doesn't GC US real GDP & 2.10 & 0.12 \\
US Real GDP doesn't GC real oil price & 0.48 & 0.61 \\
\hline
\end{tabular}


Response to Cholesky One S.D. Innovations \pm 2 S.E.

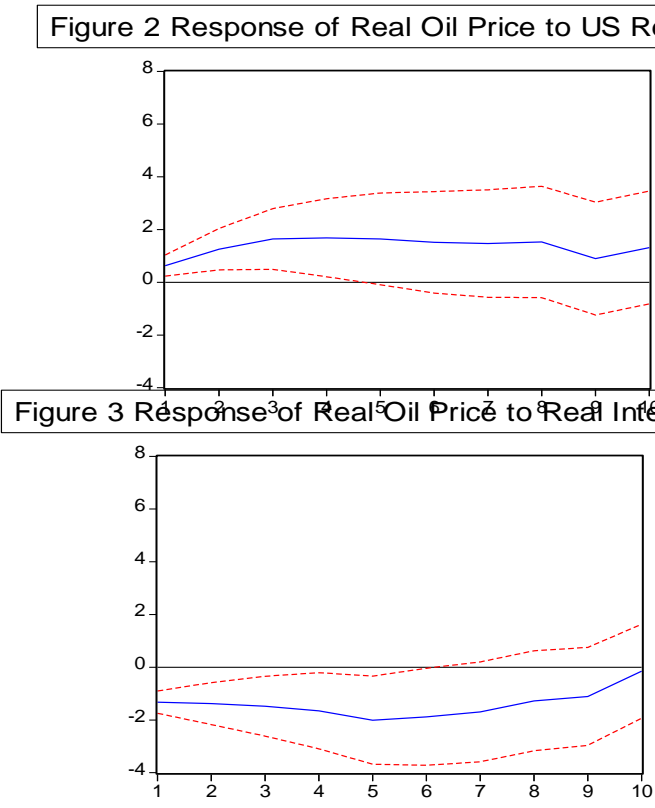

Figure 4 Response of US Real GDP to Real Oil Price

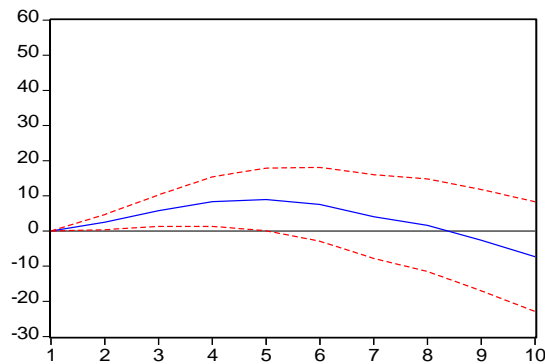

Figures 2, 3 and 4. Response to Cholesky One S.D. Innovations \pm 2 S.D.

The results in Table 3 are not supportive of real oil price not affecting global output. However, the hypothesis of global output affecting real oil price is rejected. In Table 4 the sample period is limited to 1990-2014 when the demand for oil mainly from china and India was strong.

Table 4. Granger Causality Test Results

\begin{tabular}{lll}
\hline Hypothesis & F statistics & Probability \\
\hline Real oil price doesn't GC US real GDP & 9.8 & 0.00 \\
US Real GDP doesn't GC real oil price & 5.67 & 0.00 \\
\hline
\end{tabular}

Note. The above results are based on monthly data 1990-2014.

The results in the last table reject both hypotheses, indicating that global output affects oil prices and visa verse. The results based on 70-90 (not shown here) observations rejected the hypothesis that global 
output affects real oil prices.

\section{Summary and Concluding Remarks}

The results of this study indicate that changes in global output have significant impact on real oil price fluctuations. Sharp rises in oil prices in 2008 and recent slump in price of oil are evidence of a strong influence of demand one fluctuations of energy prices. However, GC results show that the relationship between oil prices and global output in the 1990s and 2000s are both ways. The results of this study are also supportive of a negative relationship between real oil prices and real interest rates. Since the early 1970s, the impact of political developments in the Middle East is not supported by the empirical results of this study.

\section{References}

Barsky, R., \& Kilian, L. (2004). Oil and the Macroeconomy since the 1970s. Journal of Economic Perspectives, 18(4), 115-134. http://dx.doi.org/10.1257/0895330042632708

Hamilton, J. (2009). Causes and Consequences of the Oil Shock of 2007-2008. Brooking Papers on Economic Activity, Spring, 215-261. http://dx.doi.org/10.1353/eca.0.0047

Hamilton, J. (2011). Historical Oil Price Shocks (NBER Working Paper 16790). February.

International Energy Agency (IEA). (2016). Global oil stock are still building. June.

Kilian, L. (2009). Not All Oil Price Shocks Are Alike: Disentangling Demand and Supply Shocks in Crude Oil Market. American Economic Review, 93(3), 1053-1069. http://dx.doi.org/10.1257/aer.99.3.1053

Moadjemi, M., \& Lodewijks, J. (2011). Oil Price Fluctuations and the American Economy. Global Review of business and Economic Research, 42-57.

Monadjemi, M. (2011). Monetary Policy and Oil Prices. Global Economy Journal, 11(3), 8. http://dx.doi.org/10.2202/1524-5861.1730

Monadjemi, M. (2016). Oil Price Fluctuations and the Australian Dollar. International Journal of Economics Commerce and Management, 4(6), 79-89. 